\title{
Karol Mausch, Ewa Ryś (red.), Troska. Między teorią a praktyką, Gorzów Wielkopolski 2021
}

Obecny i stosowany w codziennych zachowaniach komunikacyjnych termin troska wzbudza w naszej świadomości szereg niezwykle zróżnicowanych, wręcz ambiwalentnych kategorialnie i sytuacyjnie obrazów i stanów psychicznych, przywołując np. obrazy: postaci matki czy opiekunki pochylonej nad dzieckiem, żony żegnającej męża udającego się na wyprawę wojenną, nauczyciela wspomagającego w swoich staraniach ucznia opanowującego jakiś fragment zadanej lekcji, chłopca przeprowadzającego starszą osobę przez ruchliwą ulicę, lekarza stosującego mniej lub bardziej skomplikowaną a uważną terapię osoby chorej, wolontariuszki przygotowującej i rozdającej posiłek dla licznie zgromadzonych osób bezdomnych, żołnierza, który pod kulami wroga ściąga z pola walki rannego towarzysza broni itd., itp.

Tak stosowany termin - troska - kojarzy nam się i jest używany z innymi, współokreślającymi wskazane sytuacje i zaangażowane w nie osoby, takimi jak: starania, zachowania opiekuńcze, pomocowe, ratujące, dobroczynne itp., prowokowane podmiotowym poczuciem miłości, powinności, obowiązku, spełnianych i ujawnianych wobec „naszych” osób, a zdarza się, że i wobec „innego - obcego", a więc takich, z którymi się identyfikujemy wspólnotowo, grupowo, względnie nam powierzonych w społecznie uznanych relacjach powinnościowych, zatem zasadnie oczekujących, spodziewających się, wymagających wsparcia czy pomocy z naszej strony.

$\mathrm{W}$ tym przypadku termin ten sygnalizuje nam więc pewną kategorię relacji między podmiotem i przedmiotem, świadczonego i ujawnianego bezpośrednio wsparcia sygnalizującego towarzyszące mu pewne emocjonalne i wolicjonalne stany psychiczne jego podmiotu i określone kategorie potrzeb (np. bezpieczeństwa) jego przedmiotu, wzbudzające owe stany psychiczne.

Termin ten sygnalizuje nam także istnienie w danym układzie społecznym, w jego kulturze określonych kulturowych wzorów troskliwego, starannego czy niezawodzącego zachowania społecznego - skłaniających osoby społeczne pełniące m.in. wskazane wyżej role do ich podmiotowego respektowania w środowiskach i społecznościach, w których osoby te są identyfikowane jako swoje i/lub z którymi one same się identyfikują. Wzory te wkomponowują się niejako w przepisy pełnionych przez nie ról społecznych, a ich respektowanie lub nie stanowi kryterium jakości ich pełnienia w ocenie społecznej, a tym samym przyzwolenia na ich kontynuacje, względnie zaniechanie.

Termin troska - w jego potocznej, komunikacyjnej obecności, wzbudza także szereg innych stanów świadomościowych kierujących naszą uwagę na takie dopełniające jego rozumienie terminy, 
i ich potocznie rozpoznawane znaczenia, jak: zaufanie, bezpieczeństwo, porządek - ład, sprawiedliwość, przewidywalność itp.

W tym znaczeniu rozpoznajemy lub nie jego obecność w: przepisach prawa, w wyrokowaniu sądowym, w sprawowaniu władzy wszelakiej, w rzeczywiście stosowanej strategii i taktyce walki zbrojnej, w projektowanych i egzekwowanych pasmach działań zwanych zawodowymi, a będących konsekwencją społecznego podziału pracy, lecz i w realizowaniu codziennych wzajemnych zobowiązań, w oznakowaniu, nadzorowaniu i regulowaniu ruchu drogowego, w nocnym wypieku i dostarczaniu na czas pieczywa do miejsc jego sprzedaży czy dystrybucji, w jakości wykonywanych i dystrybuowanych przedmiotów, w gwarantowaniu przez państwo bezpieczeństwa wewnętrznego i zewnętrznego, w rozważnym gospodarowaniu zasobami materialnymi, surowcowymi, kapitałem ludzkim i jego pomnażaniu (trenerskim, instruktorskim, nauczycielskim, przywódczym itp.), w planowaniu przestrzennym, $\mathrm{w}$,układaniu się" $\mathrm{z}$ naturą - $\mathrm{z}$ okupowanym środowiskiem - siedliskiem terytorium.

Tak potocznie rozumiany, stosowany i respektowany termin troska - i wyzwalane nim zachowania gwarantują ochronę szczególnie cenionego w zasadzie w każdym układzie społecznym ładu przedmiotów i czynności oraz akceptowanej społecznie ekspozycji osób, przypisywanemu wszelakim czynnościom sensu, dostrzegania i petryfikowania w świecie, w którym żyjemy, perspektywy egzystencjalnej: wewnątrz i międzypokoleniowej.

Wreszcie to coś, co rozumiemy, posiłkując się terminem troska na co dzień, identyfikowane jest z postacią naszej społecznej obecności, naszemu społecznemu „okazywaniu się” sobie i innym. Wpierw ciało i jego witalność wzorowana kulturowo, lecz i jego atrakcyjność upatrywana modnie w proporcjach poszczególnych części anatomicznych, kształtowanych właśnie z jakoś pojmowaną troską (staraniem) o ich standardowy, względnie szczególnie ceniony wygląd i spodziewaną funkcjonalność, w ich zdobieniu czy przydawaniu im cech pozostających w zgodzie z przyjętymi w danym układzie społecznym kanonami piękna - jego poszukiwaniem i smakowaniem. W dalszej kolejności w troskliwym doborze artefaktów takich, jak odzienie, okrycie głowy, zdobienia uszu, szyi, nosa, warg i zapewne wielu innych części ciała; by w końcu otaczać się przedmiotami mniej lub bardziej użytkowymi, wszakże w trosce o podmiotową atrakcyjność sygnalizowaną posiadanymi środkami, urządzeniami, lokalizacją właśnie, w trosce o zachowanie, względnie markowanie, gwarantującej (czy spodziewanej) jej społeczne odczytanie, pozycji społecznej.

Termin troska - a zwłaszcza jego potoczne rozumienie i praktykowanie - kojarzy nam się także ze zdarzeniami, działaniami i intencjami humorystycznymi (np. troska matek eksponujących swoje 5-6 letnie córki w konkursach piękności z nadzieją na spełnienie ich oczekiwanej zawrotnej medialnie, a tym samym i egzystencjalnie, kariery), wątpliwymi moralnie (vide: komunikat polskiego MNiSW z lutego 2021 r. zatytułowany: „Troska o rozwój i jakość polskiej nauki - zmiany w punktacji czasopism") czy wręcz groźnymi - odrażającymi intencjonalnie i sprawczo (np.: troska o zachowanie czystości ideologicznej w Kościele katolickim poprzez sprawne masowe likwidowanie osób uznanych arbitralnie za heretyków, szczególnie w czasach inkwizycji, masowe mordy i skazania rzeczywistych i urojonych przeciwników mafijnych rządów w państwie sowieckim, masowe mordowanie kolejnych transportów ludności żydowskiej m.in. do obozu w Oświęcimiu w trosce o czystość rasową populacji zwanej nordycką i nieskończenie wiele innych zdarzeń, sytuacji i stanów rzeczy znaczących ludzką codzienność i naszą w niej egzystencję).

Ten tak znacznie skomplikowany i ambiwalentny zasób znaczeniowy terminu troska, a więc jego wielorakie zastosowanie, rozumienie i praktykowanie nie służy bynajmniej staraniom ujawnianym wśród reprezentantów wielu dyscyplin naukowych, by uczynić zeń pojęcie teoretyczne przydatne do 
opisu i objaśniania tych aspektów i wycinków rzeczywistości psychospołecznej i społeczno-kulturowej, które umykają uwadze teoretykom konstruującym teorie podmiotowych stanów psychicznych, zachowań społecznych, stanów rzeczy, zjawisk i procesów czy pasm działań, a nawet pól praktyk społecznych, bowiem troskę $\mathrm{w}$ znaczeniu potocznym kojarzy się przeważnie $\mathbf{z}$ taką intencją spodziewanego i/lub faktycznego działania (działań) lub jego (ich) zaniechania, które skutkuje(-ą) zachowaniem bądź pozyskaniem stanu rzeczy uznawanego w danym układzie społecznym (społeczno-kulturowym), i w danym czasie historycznym, za właściwy, godny szczególnego uznania, pożądany, a nawet najlepszy z możliwych.

Właśnie owa polifonia potocznych znaczeń terminu troska i jego niejako wszechobecność w ludzkiej codzienności zafascynowała redaktorów recenzowanej monografii, podejmujących ambitną i raczej rzadko spotykaną próbę troskliwego przyjrzenia się i prześledzenia teoretycznych kontekstów jego pojęciowych operacjonalizacji i tym samym zastosowań, głównie czynionych na gruncie dyscypliny psychologicznej (wstęp i tekst Karola Mauscha Psychologia troski - otwierający recenzowany tom), aczkolwiek wskazując także na pozapsychologiczne, m.in. etyczne konteksty znaczeniowe omawianego terminu (studium Bogusława Stelcera, wydobywające ontologię troski z koncepcji etyki czci dla życia Alberta Schweitzera) oraz studium Karola Mauscha i Ewy Ryś - Troska o człowieka cierpiącego. Analiza egzystencjalna na podstawie koncepcji Alfreda Langle i Dorothee Burgi.

Wszakże zdecydowanie dominują w recenzowanym tomie teksty ukazujące zwłaszcza prakseologiczne konstrukcje operacjonalizacyjne i ich zastosowania w projektach i praktykach (ingerencjach) terapeutycznych, pedagogicznych czy socjalnych.

Natrafiamy więc w części pierwszej na teksty wiodące Czytelnika ku zabarwionym troską działaniom opiekuńczo-terapeutycznym, zarówno witalnym, jak i psychoterapeutycznym. Są to artykuły:

- Angeliki Kleszczewskiej-Albińskiej - Troska o siebie i troska o klienta w terapii w nurcie poznawczo-behawioralnym;

- Doroty Skrockiej - Decyzja o rezygnacji z pielegnowania zranień wyrazem troski o siebie czy trwałość relacji z drugim człowiekiem?;

- Przemysława Króla - „Duchowa depresja”? Melancholia i acedia. Porównanie zjawisk oraz implikacje psychoterapeutyczne w kontekście religijnym;

- Andrzeja Mieleckiego - Pomaganie czy kochanie, czyli refleksja na temat dbania o siebie i podopiecznych $w$ relacji terapeutycznej;

- Soňi Lovašowej - Samoopieka - strategia eliminacji zjawiska ryzyka oraz

- Vladimira Lichnera - Systematyczna samoopieka w pomaganiu profesjonalnym - narzędzie ograniczania ryzykownych zachowań warunkiem wstępnym opiekowania się innymi.

Kolejne teksty koncentrują uwagę Czytelnika na obecności znamion troski w polu działania socjalnego i pedagogicznego. Są to teksty:

- Ewy Wilczek-Rużyczki i Krystyny Nosal - Empatia i wypalenie zawodowe a inteligencja emocjonalna u pielegniarek;

- Agaty Matysiak-Błaszczyk i Mirosławy Ściupider-Młodkowskiej - Asystentura rodzin w sytuacji społecznych zmian;

- Anety Sylwii Baranowskiej - Pomoc imigrantom w radzeniu sobie z trudnościami w integracji w kraju przyjmującym;

- dwa teksty Joanny Dymeckiej - Funkcjonowanie psychologiczne rodziców dzieci chorych onkologicznie oraz Potrzeba kontaktu emocjonalnego u dzieci z niepetnosprawnościa intelektualna wychowywanych w placówce opiekuńczo-wychowawczej;

- Ewy Ryś - Relacje w opiece terminalnej wyrazem troski o chorego, także: 
- Karola Mauscha i Ewy Ryś - Oczekiwanie wsparcia społecznego u mieszkańców domu pomocy społecznej.

Publikację dopełnia studium socjohistoryczne Adama i Małgorzaty Czabańskich - (Bez)troska dziennikarzy piszących o przypadkach samobójstw na przykładzie „Kuriera Poznańskiego” w 20-leciu międzywojennym.

Ujawniona prezentacja zawartości merytorycznej recenzowanego tomu jednoznacznie wskazuje (poza dwoma wstępnymi studiami teoretycznymi) na lokowanie w pomieszczonych artykułach rozmaicie pojmowanego w nich i stosowanego pojęcia troski. Obecnej bądź postulowanej w relacjach międzyludzkich o charakterze pomocowym, opiekuńczym, terapeutycznym, pedagogicznym, pomijając w zasadzie sygnalizowanie i obrazowanie jej obecności np. w zachowaniach masowych, w przedsięwzięciach planistycznych, konstrukcyjnych - technicznych czy technologicznych, komunikacyjnych, organizacyjnych, biznesowych, ekologicznych, pacyfistycznych i wielu, wielu innych społecznych i indywidualnych przedsięwzięciach wzorowanych kulturowo, lecz i ewidentnie twórczych, przysparzających zasobom kulturowym kolejnych wskaźników rzeczy i stanów: dobrych, pięknych, doskonałych, oryginalnych, niepowtarzalnych itp., itd.

Wszakże ich lektura nie tylko odsłania Czytelnikowi istotę troski, postrzeganą czy obecną (postulowaną) w tych relacjach, spełniając zakładany przez ich autorów walor edukacyjny - intencjonalnie kierowany wobec służb medycznych, socjalnych, pomocowych czy opiekuńczych i wychowujących, co właśnie inspirujący, by upatrywać jej obecności w całej przestrzeni życia społecznego, będącego udziałem i doświadczeniem jednostek, a także rozlicznych struktur społecznych zarówno tych pojawiających się sytuacyjnie, współtworzących ludzką codzienność, lecz i tych, którym życie społeczne przydaje znamiona międzypokoleniowej historyczności.

Taka szeroka panorama ukazująca zróżnicowaną wewnętrznie ontologię troski, jej rozliczne aspekty i postacie, ich dynamikę i funkcje podmiotowe, lecz i społeczno-kulturowe - tak konieczne - służy temu, by wszelkie formy wspólnotowości niosły ze sobą podzielaną satysfakcję ograniczającą właśnie troski - pojmowane jako indywidualne zmartwienia i społeczne problemy (dysfunkcje, dezorganizacje, patologie).

Recenzowany tom może stanowić w tym względzie istotną inspirację zarówno dla indywidualnie czynionej praktyki społecznej, przydając jej walory inspirujące, optymalizujące czy mobilizujące, jak i jej rozlicznych postaci działania zbiorowego, wzmagając swoimi efektami te wartości, które integrują, konsolidują czy jednoczą rozliczne strukturalne formy życia społecznego. Jest on także swoistym wyzwaniem dla teoretyków i badaczy rzeczywistości podmiotowej i społeczno-kulturowej, uzasadniającym potrzebę czy wręcz konieczność podjęcia i kontynuacji studiów i badań nad ontologią troski, zwłaszcza jej ambiwalencją oraz jej (nie)obecnością w świecie tak ryzykownie wyzbywającym się jej w konstruowaniu znamion swojej teraźniejszości i zwłaszcza przyszłości. Polecam recenzowany tom zwłaszcza pedagogom społecznym, tak bardzo troszczącym się w swoich projektach teoretycznych i formach społecznego zaangażowania o dobro innego - potrzebującego.

Poznań, w lutym 2021

Jerzy Modrzewski

DOI: $10.14746 / p s n .2021 .1 .12$ 